\section{Public Health Genomics}

Public Health Genomics 2012;15:313-321

DOI: $\underline{10.1159 / 000335550}$
Received: July 8, 2011

Accepted after revision: December 6, 2011

Published online: March 8, 2012

\title{
Public Health Genomics in Spain: The Status of a Non-Existing Reality
}

\author{
I. Gutiérrez-lbarluzea ${ }^{a} \quad$ D. Ibarreta ${ }^{b} \quad$ N. Malats ${ }^{c}$ \\ on behalf of the Spanish National Task Force on Public Health Genomics \\ a Osteba, Basque Office for Health Technology Assessment, Department of Health and Consumer Affairs, \\ Basque Government, Vitoria-Gasteiz, ${ }^{b}$ Institute for Prospective Technological Studies (IPTS), Joint Research \\ Centre, European Commission, Seville, and ${ }^{\complement}$ Genetic and Molecular Epidemiology Group, Spanish National \\ Cancer Research Centre (CNIO), Madrid, Spain
}

\section{Key Words}

Health impact assessment $\cdot$ Health needs assessment • Health technology assessment $\cdot$ Public health genomics Spain

\begin{abstract}
Aims: The Public Health Genomics European Network (PHGEN) aimed, among other objectives, to identify the geographical variability and legal barriers of genomic medicine and public health genomics (PHG) at an international market, where the lack of policy coherence may limit its development in Europe. PHGEN supported the creation of National Task Forces (NTF) to overview the national settings and identify proposals in different European countries. Here we summarize the key issues which emerged during the discussions conducted within the Spanish NTF. Methods: The Spanish NTF is composed of 25 experts and key leaders in PHG-related areas of knowledge and met 3 times between January 2007 and 2008 to identify, discuss and propose recommendations for the development and use of PHG in Spain. Discussions were recorded and shared with participants for amendments. Results: We observed lack of applied knowledge on PHG, training skills and capacities on genomics of the involved specialists (gynecology, pediatrics, oncology, etc.), lack of applied research on diagnostics and knowledge on the topic in the population and mass media. Some promot-
\end{abstract}

ing factors were observed, such as plans on genetics in the different regional autonomous communities, guidance on the introduction of genomic technologies and the new regional health technology regulatory frameworks. Conclusion: Although there is a current Spanish regulatory framework for the introduction of health technologies and a published biomedical law that could be useful for the development of PHG in Spain, specific and tailored initiatives should be promoted by regional and national authorities to improve the accreditation professionals and to inform the citizens on genomic technologies in order to empower them.

Copyright @ 2012 S. Karger AG, Basel

\section{Introduction}

The current provision of clinical genetics services for those with or at risk of genetic conditions varies greatly across EU member states. While realizing that future genomics services are likely to contain more than classical services, we suggest that addressing existing differences in

The views presented here are those of the authors and do not necessarily represent those of the European Commission. For members of the Spanish National Task Force on Public Health Genomics, see table 1.

\section{KARGER \\ Fax +41613061234 \\ E-Mail karger@karger.ch}

www.karger.com
(C) 2012 S. Karger AG, Basel

$1662-4246 / 12 / 0156-0313 \$ 38.00 / 0$

Accessible online at:

www.karger.com/phg
Iñaki Gutiérrez-Ibarluzea

Osteba, Basque Office for HTA, Department of Health and Consumer Affairs Donostia-San Sebastian, 1

ES-01010 Vitoria-Gasteiz, Basque Country (Spain)

Tel. +34945019 250, E-Mail osteba7-san@ej-gv.es 
provision and ensuring that all citizens have access to effective services is an important first step. Furthermore, the costs associated with developing services and new therapeutic techniques are likely to be considerable, and it is important to prevent inequity of service. For this reason, it is recommended that all future developments should be supported by strong evidence of their clinical effectiveness, which is likely to require new ways of working to integrate public, government-funded and private initiatives.

As it is not possible to predict when and to what extent biomedical advances will give rise to effective, affordable clinical and public health interventions, it has been suggested that policies should be directed at preparing and laying down an infrastructure that permits an effective response to these developments as and when they occur. In this regard, this article includes specific recommendations that address the development of clinical genetics and public health genomics (PHG) services, evidencebased evaluation of tests and technologies that support their clinical effectiveness, capacity building, and the need to develop a balanced regulatory framework that is ethically and socially acceptable.

A further challenge is how to ensure some degree of harmonization across culturally diverse EU member states while recognizing that full and complete agreement is unlikely to be achieved given their different histories and perspectives.

The Public Health Genomics European Network (PHGEN, http://www.phgen.eu) [1] was created with the support of the European Commission (DG SANCO). Between January 2006 and March 2009, it focused on exploring and monitoring the spread of genomic knowledge through the European public health systems. The network was coordinated by experts from the Institute of Public Health NRW, the German Center for Public Health Genomics (DZPHG), Bielefeld, Germany, and the Public Health Foundation, Cambridge, UK. It was composed of 58 collaborator members belonging to 31 countries from the European Union and the European Free Trade Association-European Economic Area (EFTA-EEA) as well as 25 institutes and international networks.

The specific objectives of PHGEN were: (1) to carry out sustainable networking in PHG among the member states to promote and stimulate countries' efforts in this emerging field, (2) to identify experts in disciplines related to PHG in each of the countries, (3) to draw up an inventory of PHG-related issues not developed in each country as well as priorities for the integration of genomic technologies and knowledge into the European health systems, (4) to contribute to information exchange in or- der to standardize common genetics testing practices and to create guidelines to good practices, and (5) to identify the geographical variability and legal barriers in an international market where the lack of policy coherence may limit PHG in Europe.

For this purpose, PHGEN set up and coordinated National Task Forces (NTF) in different member states to discuss the current state of integration of genomic knowledge into health systems at country level and how to promote the effective transmission and implementation of this information to benefit the community [2]. The PHGEN Steering Group developed the NTF concept to promote and stimulate effective networking efforts in PHGEN member countries in order to achieve sustainability of discourse and institutionalization in the countries.

The organization of the NTF involved the creation of a think-tank in each country, on a variety of aspects related to PHG. Each NTF has held 3 working meetings over a period of 2 years. Each of the meetings corresponded with one of the PHGEN work phases: evaluation, policy and verification development. To date, 12 countries including Spain have carried out this initiative. The Spanish NTF (S-NTF) was constituted in January 2007 with representatives from public health, genetics, epidemiology, law, political sciences, ethics, health technology assessment, technology companies, and health authorities. Table 1 provides the names and backgrounds of the members of the S-NTF. Interdisciplinarity was a key to guarantee a distinctive public health approach. The group met 3 times during a 2-year period until completion of the PHGEN in December 2008.

One of the main issues that the group took into account was the characteristics of the Spanish Health Care System. The Spanish national system is a Beveridge-like system, financed from general tax revenue and offering almost universal coverage since 1986. Far-reaching changes have taken place since then, including the transfer of powers to the autonomous communities, which was completed in 2002, making public health one of the main pillars of the modern Spanish welfare state. Currently, 17 regional autonomous health services deal with the provision of healthcare. There is a common health benefit package defined by the Regional Health Ministries Council ('Inter-territorial board') in coordination with the Spanish Ministry of Health, Social Policy and Equity; this Ministry is responsible for international health, international health relations and agreements, and the legislation on pharmaceutical products. Regional authorities are responsible for health planning, public health and Regional Health Services management. 
Table 1. List of members that participated in the S-NTF on PHG

\begin{tabular}{|c|c|c|}
\hline Name & Institution & Profile \\
\hline Benítez, Javier & $\begin{array}{l}\text { Centro Nacional de Investigaciones Oncológicas (CNIO), } \\
\text { http://www.cnio.es }\end{array}$ & Human genetics \\
\hline Bertranpetit, Jaume & Universitat Pompeu Fabra (UPF), http://www.upf.edu/cexs/ & Human genetics \\
\hline $\begin{array}{l}\text { Briones Pérez de la Blanca, } \\
\text { Eduardo }\end{array}$ & Hospital de Valme & HTA \& organizer \\
\hline Estivill, Xavier & $\begin{array}{l}\text { Centre de Regulació Genòmica (CRG), } \\
\text { http://pasteur.crg.es/portal/page/portal/Internet }\end{array}$ & Human genetics \\
\hline Expósito, Jose & $\begin{array}{l}\text { Consejería Salud Junta de Andalucía - Plan Integral de Oncología, } \\
\text { http://www.csalud.junta-andalucia.es/principal }\end{array}$ & Clinical oncology \\
\hline García-Ribas, Ignacio & Lilly, http://www.lilly.es & Technology company \\
\hline González Díaz, Francisco & Universidad de Murcia, http://www.um.es & Law \\
\hline Granados, Alicia & $\begin{array}{l}\text { Merk Sharp \& Dohme (MSD), } \\
\text { http://www.msd.es/content/corporate/index.html }\end{array}$ & $\begin{array}{l}\text { HTA \& technology } \\
\text { company }\end{array}$ \\
\hline Gutiérrez-de-Mesa, Emma & European Commission IPTS, http://www.irc.es & HTA \& organizer \\
\hline Gutiérrez-Ibarluzea, Iñaki & $\begin{array}{l}\text { Servicio de Evaluación de Tecnologías Sanitarias (OSTEBA), } \\
\text { http://www.osakidetza.euskadi.net/osteba/en }\end{array}$ & $\begin{array}{l}\text { Health technology } \\
\text { assessment }\end{array}$ \\
\hline Hernández, Ildefonso & Universidad Miguel Hernández, http://www.dsp.umh.es/ & $\begin{array}{l}\text { Epidemiology and public } \\
\text { health }\end{array}$ \\
\hline Ibarreta, Dolores & European Commission IPTS, http://www.irc.es & PHGEN observer \\
\hline Llanos, Aurora & $\begin{array}{l}\text { Agencia de Evaluación de Tecnología Sanitaria de Andalucía (AETSA), } \\
\text { http://www.juntadeandalucia.es/salud/orgdep/aetsa/default.asp }\end{array}$ & HTA \\
\hline Malats, Núria & $\begin{array}{l}\text { Institut Municipal d’Investigació Mèdica (IMIM), } \\
\text { Centre de Recerca en Epidemiologia Ambiental (CREAL), } \\
\text { http://www.creal.cat/ }\end{array}$ & Epi - PH \& organizer \\
\hline Márquez, Soledad & $\begin{array}{l}\text { Agencia de Evaluación de Tecnología Sanitaria de Andalucía (AETSA), } \\
\text { http://www.juntadeandalucia.es/salud/orgdep/aetsa/default.asp }\end{array}$ & HTA \& organizer \\
\hline Martínez, Antonio & PROGENIKA S.A, http://212.8.105.165/elora/jobs/0045/00005/web/ & Technology company \\
\hline Muñoz, Emilio & Instituto Filosofía, CSIC, http://www.csic.es & Political sciences/ethics \\
\hline Nicolás, Pilar & $\begin{array}{l}\text { Cátedra Universitaria de Derecho y Genoma Humano, } \\
\text { http://www.catedraderechoygenomahumano.es }\end{array}$ & Political sciences/ethics \\
\hline Noguer, Isabel & $\begin{array}{l}\text { Subdirectora General de Programas Internacionales de Investigación } \\
\text { y Relaciones Institucionales, Instituto de Salud Carlos III (ISCIII), } \\
\text { http://www.isciii.es/htdocs/index.jsp }\end{array}$ & National funding agency \\
\hline Plasència, Antoni & $\begin{array}{l}\text { Direcció General de Salut Pública, Generalitat de Catalunya, } \\
\text { http://www10.gencat.net/sac/AppJava/organisme_fitxa.jsp?codi=2949 }\end{array}$ & $\begin{array}{l}\text { Competent health } \\
\text { authority }\end{array}$ \\
\hline Pollán, Marina & Instituto de Salud Carlos III, http://www.isciii.es/htdocs/index.jsp & $\begin{array}{l}\text { Epidemiology and public } \\
\text { health }\end{array}$ \\
\hline Pons, Joan $\mathrm{M}^{\mathrm{a}} \mathrm{V}$. & $\begin{array}{l}\text { Agència d'Avaluació de Tecnología i Recerca Mèdiques (AATRM), } \\
\text { http://www.aatrm.net/html/es/Du8/index.html }\end{array}$ & $\begin{array}{l}\text { Health technology } \\
\text { assessment }\end{array}$ \\
\hline Ramos, Feliciano & Asociación Española de Genética Humana (AEGH) & Scientific society \\
\hline Schröder, Peter & $\begin{array}{l}\text { Public Health Genomics European Network, } \\
\text { http://www.phgen.nrw.de/typo3/index.php }\end{array}$ & PHGEN observer \\
\hline Sempere, Antonio & Vicerrector Universidad Rey Juan Carlos, http://www.urjc.es & Law \\
\hline
\end{tabular}


Table 2. Policy recommendations by the S-NTF on PHG

\begin{tabular}{|c|c|}
\hline Topic & Recommendations \\
\hline Legal and ethical aspects & Promote the regulatory framework according to the Spanish Biomedical Research Law \\
\hline Health services & $\begin{array}{l}\text { Promote the discussion in the area in order to develop the existing regulatory framework } \\
\text { Promote the diffusion of existing guidelines on the topic }\end{array}$ \\
\hline Public health assessment & $\begin{array}{l}\text { Promote the development of frameworks that combine HNA, HTA and HIA in the public policies } \\
\text { Evaluate the value of health surveys in the establishment of priorities in public health }\end{array}$ \\
\hline $\begin{array}{l}\text { Hindering and promoting } \\
\text { factors }\end{array}$ & $\begin{array}{l}\text { Promote the development of the Biomedical Research Law } \\
\text { Promote the inclusion of the competences on genomics in certain medical specialties } \\
\text { Diffuse the use of the GANT and GEN guidelines } \\
\text { Fund applied research in PHG } \\
\text { Reinforce the activities of the NTF in order to harmonize and coordinate actions } \\
\text { Strengthen the link between the NTF and the Directorate of Public Health } \\
\text { Facilitate the recruitment of skilled professionals } \\
\text { Promote the knowledge on big cohorts of population }\end{array}$ \\
\hline Training & $\begin{array}{l}\text { Promote the development of documents or guidelines with the minimum core competences for the } \\
\text { different health professionals (they could be based on currently established pan-European initiatives } \\
\text { such as EUROGENTEST) } \\
\text { Promote and diffuse the competences in collaboration with the scientific societies in order to spread } \\
\text { those competences in the different curricula } \\
\text { Involve the primary care and community nursing in the training of the population } \\
\text { Promote the training of the members of the ethics and research committees }\end{array}$ \\
\hline Public participation & $\begin{array}{l}\text { Develop guidelines that ensure a systematic, transparent and informed involvement of the popula- } \\
\text { tion in the decision-making process on public health genomics } \\
\text { Promote the participation of the population on the investment-reinvestment processes on the health } \\
\text { care systems }\end{array}$ \\
\hline
\end{tabular}

The topics discussed during the S-NTF meetings included: legal and ethical aspects, education and training, health services, public health assessment, public policy and stakeholder involvement, hindering and promoting factors, public health education, and public participation. For each and every one of these, a set of recommendations was put forward (table 2). The results of the discussions held and the suggestions raised by the S-NTF are summarized below.

\section{Legal and Ethical Aspects}

There have been recent advances in legislation in the Spanish context. Among these changes, the Spanish Ministry of Health published the 'Ley de investigación biomédica. Ley básica de investigación’ [3]. This law established a legal framework for all health research in Spain, including genomics. In this regard, the law regulates not only biomedical research, but also how and when to car- 
ry out genetic analysis in healthcare and how to manage personal genetic data. The law includes issues related to genetic counseling and genetic tests and is in line with the Oviedo Convention on Human Rights and Biomedicine. Nevertheless, the S-NTF and other organizations have noted that there is a lack of accompanying guidance documents and development of the law itself. The gaps are related to the development of a legal framework with criteria for the accreditation of laboratories, professional development and the development and structure of biobanks. There are no established measures to ensure professional training and learning curves and to define the competences that professionals should have. The S-NTF found a similar lack of regulation at regional level (in Spain, as stated above, the autonomous regions have full responsibility in this area) [4-6]. Finally, preliminary work has been developed by the local ethics and research committees that have been involved in the management of biological samples.

The S-NTF recommended promoting and reinforcing the regulatory framework according to the Spanish Biomedical Research Law.

\section{Education and Training}

Spain suffers from a lack of knowledge and training in the field of Genetics. Genetics-Genomics is not considered as a specialty in medical schools, and professionals working in this domain come from other backgrounds with a variety of postgraduate experiences. Furthermore, the educational offer is not homogeneous. There is thus a need for legal regulation to ensure a minimum, homogeneous core set of competences for health professionals. The Spanish Society of Human Genetics (Asociación Española de Genética Humana) is leading an initiative to promote the development and establishment of Genetics as a specialty in Spain [7]. An expert committee has been created to develop this proposal. The proposal considers clinical genetics as a core specialty that could be accessed by health professionals from different backgrounds.

Furthermore, the S-NTF identified a general lack of understanding of genomic concepts in different health specialties. While some medical disciplines have already included genomics in their curricula [8], this practice has not been widespread in other fields that are yet involved in the diagnosis and treatment of genomic-related pathologies. A lack of competences on the topic has been observed among those professional members of the ethics and research committees that are involved in the evaluation and approval of research projects.

The current offer of genomic learning and training courses in Spain combines private and public initiatives. There are some, but not many, postgraduate courses and some Internet-based initiatives in Spanish universities and public health schools. Scientific and professional societies have started to provide courses in genetic counseling (postgraduate studies), but these are mostly not recognized by health authorities. Moreover, courses do not include specific training in PHG.

The S-NTF also discussed the role that private foundations play in the education of health professionals and society in general. In fact, while this is common practice in other areas of biomedical knowledge, such as chronic and acute diseases and healthcare management, it is not common practice in genomics and especially in PHG. In this regard, the group emphasized the importance of educating mass-media professionals specialized in health, given their role in disseminating health-related information.

Some regional television channels (TV3 Catalonia and ETB Basque Country) have promoted a variety of programs (telemarathon) on this topic, providing information about hereditary diseases and possible treatments, with the goal of obtaining funds for research. Although specific regional genetics plans have been published, no genomic health literacy programs have been accordingly defined.

The S-NTF recommended including PHG in the curricula of other medical specialties and promoting standard competence profiles in the various biomedical specialties involved. It is of great importance that it be included in the curricula of nursing professionals and general practitioners, as they are involved at community level and could play a role in training the population and identifying people who are at risk. This health promotion should consider involving not only the various scientific societies, but also the population at large. Accordingly, the group recommended: (a) promoting the development of documents and guidelines with the minimum core competences for the different health professionals (they could be based on currently established pan-European initiatives such as EUROGENTEST [9]), (b) incorporating genomics knowledge and skills in the training of health professionals during pre-graduate and post-graduate studies, (c) involving primary care and community nursing specialists in training the population, (d) promoting training of the members of the ethics and research committees, and (e) informing the mass media 
about the work of the S-NTF and contacting mass-media professionals in order to disseminate quality information on this topic to health professionals and the general population, organizing professional meetings with topic-specific workshops in this area.

\section{Health Services}

In Spain, the mechanism for approval and reimbursement of a new diagnostic test, as is the case for other health technologies except drugs, has been transferred to the autonomous regions. There is a basic regulatory framework, but the structure of decision-making is not well defined at the local or regional level.

Two autonomous regions have a regulatory framework in Spain (Galicia and Basque Country) $[10,11]$ at different levels of development. The group stated that there is a need for long-term follow-up and evaluation of these frameworks and their impact on the introduction, reimbursement and use of genomic technologies.

At present, a variety of European initiatives (EUnetHTA project DG SANCO [12] and the EU-funded InnoHTA project [13]) have tried to deal with the problem and have proposed some solutions, such as the existence of horizon scanning, regulated introduction and monitoring systems or post-introduction assessment of health technologies [14]. There is also a need for impact studies on cost-effectiveness, ethical, social, organizational aspects, and services to help in the decision-making process.

In Spain, 3 sets of guidelines were developed to help in the process of introducing such technologies: the GEN guidelines (Andalusian Agency for HTA) [15]; Economic evaluation guidelines (Osteba), which defined the framework for economic studies of health technologies [16]; and a toolkit for the development of health economics evaluation studies (Servicio Canario de Salud), including genomic technologies [17].

The S-NTF recommended promoting discussion in the area in order to develop the existing regulatory framework and the distribution of existing guidelines on the topic. It would be also interesting to put the current regulatory into practice framework in order to define the common benefit package in the area of genomic technologies to avoid inequities among autonomous regions.

\section{Public Health Assessment}

Spain lacks a framework that combines Health Needs Assessment (HNA), Health Technology Assessment (HTA) and Health Impact Assessment (HIA). There are a variety of separate initiatives that use some of them. Andalusia has some initiatives introducing HIA into public health policies. The Basque Country has local experience of HIA of public policies [18], but not of PHG. In Catalonia, there is a combined initiative to identify health research needs from an HTA perspective [19]. The Spanish and regional Health Surveys serve to roughly identify public health needs, but this information is not used for establishing public health priorities. The Spanish National Health System should be aware of existing projects at European level that combine them. Any developments should be in line with existing PHGEN initiatives.

In this regard, the S-NTF recommends promoting the development of frameworks that combine HNA, HTA and HIA in public policies and assess the value of health surveys in establishing public health priorities. Spanish authorities at all decision-making levels should ensure that Spanish genomics-related organizations, such as the S-NTF, are involved in European initiatives.

\section{Public Policy and Stakeholder Involvement}

The S-NTF agreed that it is of great importance to inform the decision-makers of its activities and all the recommendations produced during the 3 meetings.

For that purpose, it seems necessary to write a white paper or a document including all the discussions and recommendations extracted from the meetings, distributing them widely. The possible stakeholders to whom the document should be sent were proposed by the members of the NTFG, a group which included the following public policy decision-makers: Quality Agency for the Spanish Health System, Public Health General Directorate, Cohesion and Public Policies General Directorate, Carlos III Institute for Research, Ministry of Science and Innovation, Health Technology Assessment Agencies Directors, Public Health Schools Directors and Ministers of Health of the Spanish autonomous regions, and the Scientific Societies (see table 3, summarizing the role of each stakeholder).

Specifically, the S-NTF recommended drafting a document containing the discussions and recommendations of the NTFG, distributing the document among stake- 
Table 3. Principal stakeholders in Spain related to PHG and their role

\begin{tabular}{|c|c|}
\hline Stakeholder & Role and responsibilities \\
\hline Quality Agency for the Spanish Health System* & $\begin{array}{l}\text { Development and implementation of health policies for continuous health im- } \\
\text { provement, elaboration of decision-making tools, promotion of health informa- } \\
\text { tion and evaluation systems }\end{array}$ \\
\hline Public Health General Directorate* & $\begin{array}{l}\text { Epidemiological data, health promotion and disease prevention, external health, } \\
\text { occupational health, environmental health and hygiene and sanitary require- } \\
\text { ments of the products of human use and consumption, and the development of } \\
\text { regulations in these matters }\end{array}$ \\
\hline Cohesion and Public Policies General Directorate* & $\begin{array}{l}\text { Management of health professions, to arrange and manage specialized training } \\
\text { in health sciences and the accreditation system of continuing education of } \\
\text { health professions } \\
\text { Develop and update the benefit package of the National Health System }\end{array}$ \\
\hline Health Technology Assessment Agencies Directors & Inform decision-making processes at the national, regional and local levels \\
\hline Public health schools & $\begin{array}{l}\text { Promote and develop learning and training programs and research activities at } \\
\text { the national and regional levels }\end{array}$ \\
\hline $\begin{array}{l}\text { Directors and Ministers of Health of the Spanish } \\
\text { Autonomous Regions }\end{array}$ & Health planning, public health and regional health services management \\
\hline Scientific societies & $\begin{array}{l}\text { Promote research and learning and training activities in their specific field of } \\
\text { knowledge }\end{array}$ \\
\hline
\end{tabular}

* Spanish Ministry of Health, Social Policy and Equity. ${ }^{* *}$ Ministry of Science and Innovation.

holders in order to implement the recommendations and promoting regular contact with the public policy decision-makers. The group also suggested that the S-NTF should be considered as a public advisor on public health policies on this topic and a reference for all the actions adopted in Spain. The S-NTF should be a stable group of experts in the area. Currently the group has no legal status and is formed of well-positioned professionals with shared interests in PHG.

\section{Hindering and Promoting Factors}

Among the main hindering factors identified, the S-NTF focused on the lack of applied knowledge in PHG, the lack of genomics training, skills and capacities among the involved specialists (gynecology, pediatrics, oncology, etc.), the lack of applied research in diagnostics, and the lack of knowledge on the topic in the population and mass media. Some promoting factors were also pointed out: recent genetics plans in the different regional autonomous communities, the existence of guidance on the correct introduction of health technologies (GANT guideline) [20] and specifically genomic technologies (GEN guidelines) [15] at Spanish level and the regulatory frameworks as is the case of 2 autonomous regions (Galicia and Basque Country) [10,11]. Notwithstanding, some other promoting factors were described: the S-NTF received express support from the Spanish Ministry of Health's Directorate of Public Health, the recent development and establishment of a Law on Biomedical research [3] and the inclusion of Genetic counseling as part of the minimum, standard healthcare benefit package. Today, there are also some medical specialties that have included genomics-related knowledge, skills and attitudes in their curricula (biochemistry, anatomical pathology and internal medicine) [8]. It was also found necessary to promote genomics-related knowledge among the population. The pathology-treatment paradigm has changed; we are talking about healthy population and 
not about ill people in most cases. Finally, it was raised that there is a lack of recognition in those professionals working in the area and an absence of an organization that harmonizes and coordinates actions on the topic. Moreover, at Spanish level, there is serious difficulty in terms of recruitment and job stabilization of skilled professionals in the area because of the lack of accreditation of these professionals.

To improve implementation of this specific topic, the group recommended: development of the Biomedical Research Law [3], inclusion of genomics in certain medical specialties, widespread use of the GANT [20] and GEN guidelines [15], requests for funds to support applied research in PHG, reinforcing the activities of the NTF in order to harmonize and coordinate action, strengthening the link between the NTF and the Directorate of Public Health, facilitating the recruitment of skilled professionals, and promotion of knowledge among big cohorts of the population.

\section{Public Health Genomics Education}

Regarding PHG education, the group argued that there is a need to establish quality assurance models for genomics information and research. Citizenship should be taken into account in the decision-making process because citizens are mainly the receivers and owners of the information derived from genomics. It is also necessary to fight fraud with regard to genomic information and diagnostic remarks. The medical scientific societies, especially those for Primary Care, should be involved in the process; they are involved mainly at community level and are key players in informing and providing the population with access to the health system and should be part of the information process on genomics and general counseling. The group discusses the need for a genomics glossary in order to train and clarify the process for all involved stakeholders. The mass media should also be involved and trained in order to produce accurate information on genomics that could prevent fraud, misleading information, omissions, and unrealistic expectations.

The S-NTF recommends the establishment of quality assurance models for the introduction of genomic technologies and the use and development of information on the matter, promoting the development and publishing of a genomics glossary, and involving the mass media in the quality assurance process for genomics-related information.

\section{Public Participation}

In recent years, there has been a clear improvement in involving the population in the development and establishment of healthcare recommendations. As a matter of fact, the drafting of quality clinical practice guidelines (CPG) should necessarily include the opinions and preferences of patients. Patients have already been involved in CPG elaboration in Spain, including genomic technologies. In fact, members of patient associations for rare diseases have collaborated with HTA agencies and units and other CPG drafters, and HTA agencies and units have collaborated or participated in training and learning courses run by patient associations such as Eurordis and its partner associations in Spain (http://www.eurordis. org/es/member_search?country=Spain). The processes described above should be a constituent part of PHG projects, plans and documents. Moreover, the group considered that the population should be involved from the beginning, even in health care systems' investmentappropriateness-disinvestment processes. Nevertheless, such involvement should be based on prior training of the population in collaboration with patients' associations in order to promote an informed and systematic process. Genomics knowledge should be considered as a research design where all the agents should be involved and informed.

Public participation can be ensured by cooperation with the mass media professionals who transfer and translate news from conferences, etc. Furthermore, patient organizations and multipliers should be involved in PHG development. At European level, application of public participation methods is recommended to support a network of NTF and to establish a European-wide forum for interdisciplinary discussions including patient organizations.

The recommendations of the S-NTF were to develop guidelines that ensured systematic, transparent and informed involvement of the population in the decisionmaking process on $\mathrm{PHG}$ and to promote the participation of the population in the healthcare system investmentdisinvestment processes.

\section{Conclusions}

The S-NTF aimed to improve interactions between public health researchers, professionals and national policy-makers in order to provide a more specific member state approach at the wider EU level. NTFs are a way to 
achieve best-practice exchange in a multidisciplinary environment. By summing up the different member state experiences and at the same time promoting inter-disciplinary interaction in public health, the overall genomics translational capacity in Europe will be positively influenced.

As biological and medical sciences move forward, traditional legal concepts such as market authorization of medical devices and pharmaceuticals come under pressure. It will become inevitable for the European Commis- sion to address the challenges deriving from genomebased knowledge. Spain now has a well-structured regulatory framework for genomics research with the Law on Biomedical Research, but not ad-hoc complementary regulations that govern concrete situations.

The S-NTF deemed it extremely important to be aware of different initiatives at European level and to form a permanent secretariat of NTFs (possibly through PHGEN), to help harmonize the results of the PHGEN II project at national, regional and local levels [21].

\section{References}

1 Public Health Genomics European Network (PHGEN). http://www.phgen.eu.

2 National Task Force results and policy. http://www.phgen.eu/typo3/index. php?id=139.

3 Ley 14/2007, de 3 de julio, de investigación biomédica (Boletin Oficial del Estado de 4 de julio de 2007).

4 Plan de Genética de Andalucía. Consejería de Salud. Junta de Andalucía. http://www. juntadeandalucia.es/fundacionprogresoysalud/medias/File/PlanGeneticadeAndalucia.pdf.

5 Orden 3 de agosto de 2009 (BOJA de agosto de 2009), creación figura de Facultativo de Genética Clínica. http://www.juntadeandalucia.es/compromisos20082012/archivos_ repos/0/735.pdf.

6 Group for the development of Genetics in the Basque Autonomous Country: Plan para el desarrollo de la genética en la Comunidad Autónoma del País Vasco. Vitoria-Gasteiz, Department of Health and Consumer affairs, Basque Government, 2011.

7 Spanish Society of Human Genetics. http:// www.aegh.org.

8 Real Decreto 127/1984 (BOE 11 de enero). Regulación especialidades. http://www.boe. es/aeboe/consultas/bases_datos/doc. php?id=BOE-A-1984-2426.

9 EUROGENTEST. http://www.eurogentest. org/web/info/public/unit6/documents. xhtml.

10 Consellería de Sanidade de Galicia. 'Orde do 28 de novembro de 2007 pola que se regula o procedemento de incorporación de técnicas, tecnologías ou procedementos á carteira de servizos do sistema sanitario público de Galicia'. DOG, no. 238, p19507. http://www. xunta.es/Dog/Dog2007.nsf/FichaContenido/ 4E092?OpenDocument (accessed February $28,2011)$.
11 Departamento de Sanidad, Gobierno Vasco: 'Procedimiento para la incorporación de tecnologías sanitarias en la práctica asistencial del sistema sanitario de Euskadi'. Orden de 12 de noviembre de 2004. BOPV no 232, 3/12/2004, p 21962. http://www.euskadi.net/cgi-bin_k54/ bopv_20?c\&f=20041203\&s=2004232 (accessed February 28, 2011).

12 EUnetHTA project. http://www.eunethta. net.

13 HTA-methodology for innovative healthcare technologies (Inno-HTA): http://www. inno-hta.eu/.

14 Varela Lema L, Ruano Raviña A, Cerdá Mota T, Blasco Amaro JA, Gutiérrez Ibarluzea I, Ibargoyen Roteta N, Imaz Iglesia I, Sampietro-Colom L, Soto Pedre E, Villegas Portero R: 'Observación post-introducción de tecnologías sanitaria. Observación post-introducción de tecnologías sanitarias'. Guía metodológica. Versión abreviada. Plan de Calidad para el Sistema Nacional de Salud del Ministerio de Sanidad y Política Social. Axencia de Avaliación de Tecnoloxías Sanitarias de Galicia; 2007. Informes de Evaluación de Tecnologías Sanitarias: avalia-t No 2007/02. http://aunets.isciii.es/ficherosproductos/120/avalia07-02-3.pdf (accessed May 28, 2011).

15 Márquez Calderón S, Castilla Alcalá JA, Briones Pérez de la Blanca E, Carriazo Pérez de Guzmán A: Guide for decision-making on the introduction of new genetic tests in the National Health System (GEN Guide). Madrid: Plan Nacional para el SNS del MSC. Agencia de Evaluación de tecnologías Sanitarias de Andalucía, 2006. Informes de Evaluación de Tecnologías Sanitarias. AETSA 2006/04. http://www.juntadeandalucia.es/ salud/servicios/contenidos/aetsa/pdf/__ AETSA_2006-04_GEN.pdf.
16 Osteba. Servicio de Evaluación de Tecnologías Sanitarias. Departamento de Sanidad del Gobierno Vasco. Guideline for the Economic Evaluation in the Health Sector. Vitoria-Gasteiz: Gobierno Vasco. Departamento de Sanidad. Dirección de Planificación y Evaluación Sanitaria, 1999. http:// www 9.euskadi.net/sanidad/osteba/ datos/d_99-01_evaluacion_economica.pdf.

17 López-Bastida J, Oliva J, Antoñanzas F, García-Altés A, Gisbert R, Mar J, Puig-Junoy $\mathrm{J}$ : Spanish recommendations on economic evaluation of health technologies. Eur J Health Econ 2010;11:513-520. http://www. ispor.org/regional_chapters/Spain/documents/Spanish-recommendations-on-economic-evaluation.pdf.

18 Bacigalupe A, Esnaola S, Calderón C, Zuazagoitia J, Aldasoro E: Health impact assessment: a tool to incorporate health into nonsanitary interventions (in Spanish). Gac Sanit 2009;23:62-66.

19 Berra S, Sánchez E, Pons JM, Tebé C, Alonso J, Aymerich M: Assessment of a systematic method to prioritise health research needs in Catalonia. 5th Annu Meet, Health Technology Assessment International (HTAi), Montreal, July 2008.

20 Cerezo Espinosa de los Monteros JJ, Villegas Portero R: Actualización de la Guía para la Adquisición de Nuevas Tecnologías (GANT). Madrid: Plan Nacional para el SNS del MSC. Agencia de Evaluación de Tecnologías Sanitarias de Andalucía (AETSA), 2006. Informes de Evaluación de Tecnologías Sanitarias. AETSA No 2006/02. http://www.juntadeandalucia.es/salud/servicios/contenidos/ nuevaaetsa/up/AETSA_2007-19_Incorporacion_Nuevas_Tec.pdf.

21 Public Health Genomics European Network (PHGEN) II Project. http://www.phgen.eu/ typo3/index.php. 